\title{
Occurrence of Campylobacter fetus subsp. venerealis and Tritrichomonas foetus dna in bulls from Alagoas State, Brazil
}

\section{Ocorrência de dna de Campylobacter fetus subsp. venerealis $e$ Tritrichomonas foetus em touros no Estado de Alagoas, Brasil}

\author{
Glaucia Grazielle Nascimento ${ }^{1 *}$; Pollyanne Raysa Fernandes de Oliveira²; \\ Edson Moura da Silva ${ }^{2}$; Rinaldo Aparecido Mota ${ }^{3}$; \\ José Wilton Pinheiro Junior ${ }^{3}$
}

\begin{abstract}
The aim of the present study is to diagnose the occurrence of infections caused by Campylobacter fetus subsp. venerealis and Tritrichomonas foetus in reproducer bulls from Alagoas State breeders, Brazil. The total of 162 preputial smegma samples were collected from nelore bulls from ten rural properties in the East, Agreste and Sertão mesoregions. The samples were subjected to the Polymerase Chain Reaction (PCR) technique in order to assess C. fetus subsp. venerealis and Tritrichomonas foetus DNA and cultivated in Modified Diamond Medium (DMM) for Tritrichomonas foetus isolation. Four point nine percent $(4.9 \%-8 / 162)$ of the evaluated bulls were infected with $C$. fetus subsp. venerealis and $3.0 \%(5 / 162)$ of the sample were infected with $T$. foetus, which was not isolated in any of the assessed animals. Based on our results, there was C. fetus subsp. venerealis and T. foetus DNA in bulls from Alagoas State, Brazil. Accordingly, it is necessary performing laboratory examinations in animals living in properties breeding animals for reproduction purpose in order to monitor and control such infections. Key words: Campylobacteriosis. PCR. Bulls. Trichomoniasis.
\end{abstract}

Resumo

Objetivou-se com esta pesquisa diagnosticar a ocorrência das infecções por Campylobacter fetus subsp. venerealis e Tritrichomonas foetus em touros, provenientes de propriedades localizadas no estado de Alagoas, Brasil. Foram coletadas 162 amostras de esmegma prepucial de touros da raça nelore, procedentes de dez propriedades rurais das mesorregiões Leste, Agreste e Sertão. Para a pesquisa de DNA de C. fetus subsp. venerealis e Tritrichomonas foetus as amostras foram submetidas à técnica Reação em Cadeia da Polimerase (PCR) e para isolamento de Tritrichomonas foetus foram cultivadas em Meio Diamond Modificado (DMM). Observou-se a ocorrência da infecção por C. fetus subsp. venerealis em 4,9\% (8/162) dos touros analisados e 3,0\% (5/162) para $T$. foetus. Não foi isolado $T$. foetus em nenhuma das amostras analisadas. Os resultados deste estudo confirmam a ocorrência de DNA de C. fetus subsp. venerealis e T. foetus em touros no estado de Alagoas, Brasil. Desta forma, constata-se a necessidade da realização de exames laboratoriais em propriedades de bovinos destinadas

${ }^{1}$ Pós-Graduanda em Ciência Animal Tropical, Universidade Federal Rural de Pernambuco, UFRPE, Campus Dois Irmãos, Recife, PE, Brasil. E-mail: grazynasc@gmail.com

2 Pós-Graduandas em Biociência Animal, UFRPE, Campus Dois Irmãos, Recife, PE, Brasil. E-mail: pollyanne_raysa_fernandes@ hotmail.com; emoura.silva@hotmail.com

3 Profs. Drs., Departamento de Medicina Veterinária, Laboratório de Bacterioses, UFRPE, Campus Dois Irmãos, Recife, PE, Brasil.E-mail: rinaldo.mota@hotmail.com; wiltonjrufrpe@gmail.com

* Author for correspondence 
à reprodução para um monitoramento e controle dessas infecções.

Palavras-chave: Campilobacterioses. PCR. Touros. Tricomonose.

\section{Introduction}

Bovine reproductive diseases influence herd's reproduction efficiency and, consequently, lead to significant economic losses. Moreover, lower reproduction success can be related to the presence of specific pathogens that in most cases are not diagnosed (BELLOWS et al., 2002).

Bovine genital campylobacteriosis and trichomoniasis are caused by Campylobacter fetus subsp. venerealis and Tritrichomonas foetus, respectively. The infection caused by classical agents mainly happens at coitus through natural service (BONDURANT, 2005). These diseases have been mainly reported in extensive cattle production system due to the adopted reproduction management practices, which are often based on natural bred (MOLINA et al., 2013).

The infected bull becomes a reservoir and does not present the clinical signs of both diseases, fact that allows agents to long insidiously in herds. The difficulty in identifying the infected bulls, along with inappropriate management practices, makes intra-herd pathogen outbreak easy (MADOROBA et al., 2011).

Reproductive losses resulting from the herein addressed diseases are represented by infected animals' discharge and replacement (MADOROBA et al., 2011). Moreover, lack of diagnosis and monitoring are some of the factors contributing to the limited knowledge about the adverse effects caused by these diseases (MICHI et al., 2016).

Although bovine genital campylobacteriosis and trichomoniasis are Compulsory Notification Diseases (CND), there is no specific regulation about the need of diagnostic tests applied for bull trading purposes (MICHI et al., 2016). Such lack of regulation may favor the shortage of information about the real epidemiologic situation of such diseases (SWAI et al., 2005).

The aim of the present study was to diagnose infection caused by $C$. fetus subsp. venerealis and $T$. foetus in producer bulls from breeder farms located in Alagoas State, Brazil.

\section{Material and Methods}

\section{Study site}

The research was conducted in ten counties located in Alagoas State mesoregions: East Alagoas (7) - Capela, Chã Preta, Igreja Nova, Jacuípe, Pindoba, Porto Calvo and Viçosa; Agreste (2) Lagoa da Canoa and Olho d'Água Grande; Sertão (1): Jacaré dos Homens (Figure 1).

\section{Sampling}

Ten rural properties focused on bovine reproduction were selected through nonprobabilistic convenience. The number of farms was limited since only few of them in Alagoas State are focused on breeding bovine reproducers of high genetic standard. The total of 1.264 .053 bovines was taken into account to compose the sampling study (IBGE, 2016). The expected prevalence was $1.8 \%$ for C. fetus subsp. venerealis (OLIVEIRA et al., 2015) and $6.6 \%$ for $T$. foetus (OLIVEIRA et al., 2016 ), at confidence interval $95 \%$ and statistic error $5 \%$. These parameters set the minimum sample of 28 bulls for bovine genital campylobacteriosis analysis and of 95 for trichomoniasis bovine evaluations. We herein collected 162 preputial smegma samples from nelore bulls in the age group 24 months or older, at sexual rest of 7-15 days. 
Figure 1. Study site, counties holding bovine breeders focused on reproduction that compose East, Agreste and Sertão Alagoas.

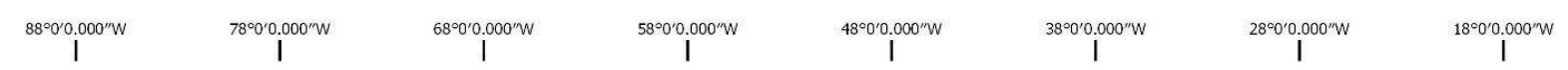<smiles>C1CCCC1</smiles>

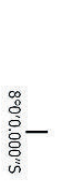<smiles>C1CCCC1</smiles><smiles>C1CCCC1</smiles>
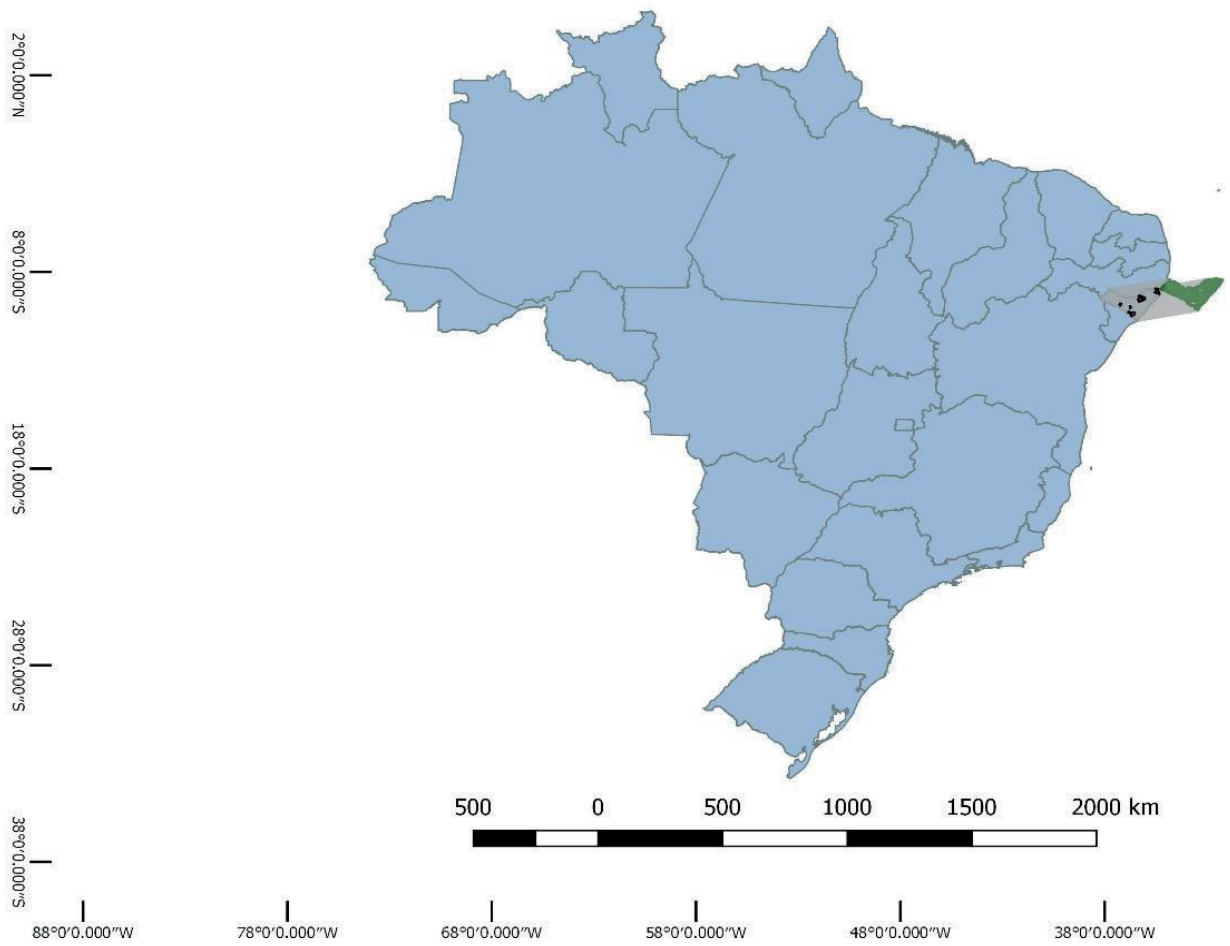

$-$

产-
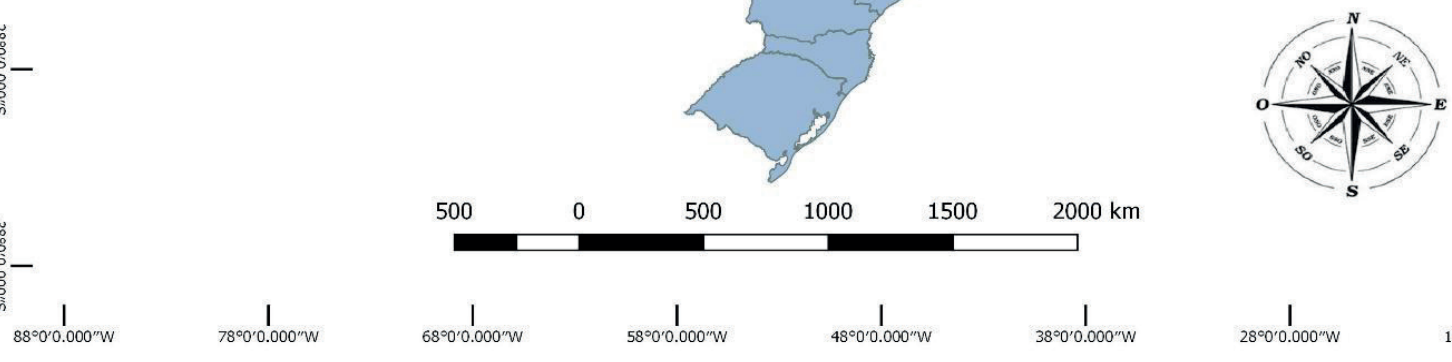

\section{Biological material collection}

Preputial ostium haircut and sanitation with water and $70 \%$ alcohol were performed after animal restraining; water and alcohol excess were dried with the aid of paper towel. Next, a specific sterilized scraper was used for smegma collection; it was introduced in the preputial ostium to smear the preputial smegma. The biological material was transferred to flacon tubes containing $4 \mathrm{~mL}$ of PBS (pH 7.2) after smearing. Subsequently, $1 \mathrm{ml}$ of sample was transferred to Diamond Modified Medium (DMM) for T. foetus isolation purposes. The samples were stored at room temperature and taken to the laboratory for proper processing.

\section{DNA extraction}

Smegma samples stored in DMM were subjected to DNA extraction in commercial "Wizard ${ }^{\circledR} \mathrm{SV}$ Genomic DNA Purification System" (Promega ${ }^{\circledR}$ ) kit, according to the manufacturer's protocol. The extracted DNA was analyzed and quantified in $1.5 \%$ agarose gel and molecular weight marker $100 \mathrm{pb}$, stained with Blue Green (LGCbio), visualized under ultra-violet light, and photo-documented in order to have its quality checked.

\section{Molecular diagnostic tests}

The amplification reactions of Campylobacter fetus subsp. venerealis genomic material was carried out with oligonucleotides VenSF 
(5'CTTAGCAGTTTGCGATATTGCCATT3') and VenSR (5'GCTTTTGAGATAACAATAAGA GCTT3'), after sample DNA extraction. The reactions were amplified to $142 \mathrm{pb}$, according to the protocol set by Hum et al. (1997).

Oligonucleotides TFR3 (5'CGGGTCTTCCTA TATGAGACAGAACC3') and TFR4 (5'CCTGC CGTTGGATCAGTTTCGTTAA3') were used in T. foetus. The reactions were amplified to $310 \mathrm{pb}$, according to the protocol set by Felleisen (1997).

Reference DNA samples were used as the positive control of each agent and ultra-pure water was the negative control. The amplified material was detected through electrophoresis in $1.5 \%$ agarose gel stained with Blue Green (LGCbio), visualized under ultra-violet light and photo-documented.

\section{T. foetus isolation}

The DMM samples were incubated in microbiological stove at $37^{\circ} \mathrm{C}$ for 72 hours to isolate
T. foetus. The samples were examined in dark-field microscope every 24 hours. Positive cultivation confirmation was based on the visualization of at least one living flagellated trophozoite presenting characteristic abrupt and undulating moves on each slide (DUFERNEZ et al., 2007).

\section{Results}

The occurrence rate of infection caused by $C$. fetus subsp. Venerealis was $4.9 \%(8 / 162)$ and of $3.0 \%(5 / 162)$ for $T$. foetus when the PCR method was adopted. Isolation did not show T. foetus in any of the assessed samples.

Results of infections caused by C. fetus subsp. venerealis and $T$. foetus in bulls distributed by property are shown in Table 1. Co-infections were not observed in the analyzed animals; however, of the five propertys presenting positive animals, two (40.4\%) had animals positive for Campylobacter fetus subsp. fetus or Tritrichomonas foetus.

Table 1. Occurrence of infections caused by Campylobacter fetus subsp. venerealis and Tritrichomonas foetus in bulls distributed by rural property focused on bovine reproduction in Alagoas State, Brazil.

\begin{tabular}{ccccc}
\hline PROPERTY & REGION & N. OF SAMPLES & C. fetus subsp. venerealis & T. foetus \\
\hline A & EAST & 17 & $5.9 \%(1 / 17)$ & $5.9 \%(1 / 17)$ \\
B & EAST & 18 & $27.8 \%(5 / 18)$ & $16.7 \%(3 / 18)$ \\
C & SERTÃO & 2 & - & - \\
D & EAST & 15 & - & - \\
E & AGRESTE & 4 & - & - \\
F & AGRESTE & 6 & - & - \\
G & EAST & 28 & - & - \\
H & EAST & 21 & $4.8 \%(1 / 21)$ & - \\
I & EAST & 33 & $3.0 \%(1 / 33)$ & $5.6 \%(1 / 18)$ \\
J & EAST & 18 & - & \\
\hline
\end{tabular}

\section{Discussion}

The present study is pioneer in reporting infection caused by $C$. fetus subsp. venerealis and T. foetus in bulls from Alagoas State, Brazil. The herein recorded results are similar to records from other Brazilian states (LEAL et al., 2012; OLIVEIRA et al., 2015), as well as from foreign countries, where there is prevalence lower than 10\% (SWAI et al., 2005; MADOROBA et al., 2011; MOLINA et al., 2013). Higher infection prevalence has been reported; however, it is worth highlighting that variations in outcomes may result from sampling design, animal's age, sanitation and reproductive management, and from the adopted diagnostic 
method. Madoroba et al. (2011) state that other variables, such as herd size and geographic area, can influence results in different researches.

Despite the low C. fetus subsp. venerealis (4.9\%) and T. foetus $(3.0 \%)$ occurrence in the present study, the importance of including the diagnosis of these agents in bulls from breeders focused on reproduction is noteworthy. These animals are reservoirs and can spread the agents through natural bred or through artificial insemination with contaminated semen (EAGLESOME; GARCIA, 1997; CAMPERO; COBO, 2006). Infections caused by these pathogens are enzootic, mainly in beef cattle bred in extensive cattle production systems, wherein sanitation control is poor and animals reproduce through natural bred, clean-up bull and artificial insemination with contaminated semen (BONDURANT, 2005).

Since bulls are asymptomatic, they should not stay with the herds, because the newly acquired animals in it must be infection-free. That is the reason why regulation tests must be conducted before the breeding season. Brazil does not have specific Bovine Genital Campylobacteriosis and Trichomoniasis control and eradication programs; however, it is recommended to replace the infected animals by younger bulls with health certificate (TRUYERS et al., 2014; YINZHU et al., 2014). With regard to Campylobacteriosis, it is possible associating antibiotics and vaccination (BONDURANT, 2005), but antibiotic therapy presents limited efficacy (MICHI et al., 2016).

Reproduction management in the visited breeders associates artificial insemination and natural bred with clean-up bull in females who did not have pregnancy confirmation 30 days after artificial insemination. It is known that the natural bred with infected animals and the use of cleanup bull in positive herds are risk factors for these sexually transmitted diseases (PELLEGRIN et al., 1999). The use of contaminated semen in association with natural bred are risk factors that enable $C$. fetus subsp. venerealis and T. foetus outbreak maintenance in bovine herds; consequently, these cows can be infected and infect other bulls in the herd (HANCOCK et al., 2015).

Collections showed that breeders who had positive animals recorded bull:female relation $1: 30$, on average, thus evidencing the possible outbreak potential of these pathogens in females. Such result can considerably influence herd reproduction indices. It is essential identifying infected bulls due to epidemiological aspects, since these animals can have contact with a large number of females throughout the reproduction period, fact that can facilitate agent transmission (HUM et al., 2009; MSHELIA et al., 2010). According to the review carried out by Bondurant (2005), T. foetus transmission rate through natural bred from infected bulls to susceptible females varies from $30 \%$ to $70 \%$. The study conducted by Waldner et al. (2017) showed that herds presenting at least one infected bull had their pregnancy rates 2.35 times lower than herds without contaminated bulls.

With regard to the number of breeders with positive animals, $40 \%$ and $30 \%$ of them had at least one animal infected with Campylobacter fetus subsp. venerealis and T. foetus, respectively. One hundred percent $(100 \%)$ of these breeders were located in East Alagoas State and traded reproducers with neighbor regions. However, based on the adopted sampling design, it is not possible stating that animals bred in the East region are more prone to infections caused by these agents, since the sanitation and reproductive managements adopted in all its properties were similar. The study carried out by Molina et al. (2013) in Argentina did not show homogeneous distribution of these diseases among different regions countrywide. They also indicated that the risk factors are similar for both infections.

It was observed that $100 \%$ of breeders have miscarriage records. Infection caused by $C$. fetus subsp. venerealis leads to reproductive issues such 
as temporary infertility, heat repetition, embryonic death and miscarriage (JIMENEZ et al., 2011). Besides the aforementioned clinic signs, pyometra was observed in approximately $5 \%$ of cows with Trichomoniasis, due to the bacterial contamination that happens when the fetus is lost (BURNS et al., 2010).

The lack of infected-animal diagnosis enables agent maintenance, and consequences deriving from the infection mainly compromise cows' reproductive function (GONZÁLEZ-CARMONA et al., 2012; YAO et al., 2015). Thus, it is possible recording significant losses due to infertility and miscarriages, and it increases the interval between labors and calf production decrease (MARDONES et al., 2008).

Most positive samples in our study were from bulls in the mean age group 3.5 years. However, the age of animals positive for C. fetus subsp. venerealis and $T$. fetus in property B was 5 years or older. Young and old bulls present different ability to harbor $C$. fetus subsp. venerealis and $T$. foetus. The mucosa of bulls older than 5 years has a larger number of folds and deeper crypts, which can reduce oxygen supply and favor the susceptibility to infections caused by anaerobic microorganisms (CLARK et al., 1974). Overall, young bulls can produce less smegma in their penile mucosa, where folds and crypts are poorly developed. Such process impairs the establishment and persistence of microorganisms. In addition, one must take into account that young animals are more resistant to infection (EAGLESOME, GARCIA, 1997; MICHI et al., 2016).

Co-infections of both agents were not observed in the present study; however, two breeders (A and B) had Campylobacter fetus subsp. venerealis and $T$. foetus positive animals. Biological material collection in these two rural properties was performed before the bred season, and it may have favored a more precise diagnosis of both agents. The biological material collection time can influence infection-prevalence results, since the concentration of these agents in the preputial smegma tend to be weaker during the bred season (MOLINA et al., 2013).

It was not possible isolating T. foetus in any of the collected samples. These results are similar to those recorded by Rocha et al. (2009) and Mai et al. (2013), who did not isolate T. foetus in bull preputial-wash samples. The non-isolation of the agent may due to the parasite's low concentration in the analyzed samples, since $3.0 \%$ of the samples were positive in PCR. The PCR technique is the most sensitive in comparison to isolation, because it enables detecting the parasite's DNA even at low concentrations (MUTTO et al., 2006).

Although the parasite was not detected in the culture, it was possible visualizing mobile and round-shaped structures during the microscopic analysis. T. foetus morphological changes into the pseudocysts form have been reported (PEREIRANEVES et al., 2003; PEREIRA-NEVES; BENCHIMOL, 2009). Pereira-Neves et al. (2011) demonstrated that $T$. foetus pseudocysts are found in the fresh preputial smegma from bulls. These changes can be attributed to stress conditions such as room temperature variations and inhibitors of cultivation medium constituents (ONDRAK, 2010).

Regular bull-monitoring programs concerning venereal diseases become necessary, since they aim at reducing infection risks and, consequently, at improving bovine reproduction indices in order to increase production, profitability and sustainability, mainly when it influences the number of calves born per year. It is worth taking into account that this is one of the most important variables affecting the economic efficiency in bovine herds (COLLANTES-FERNÁNDEZ et al., 2014).

\section{Conclusion}

The occurrence of infections caused by C. fetus subsp. venerealis and T. foetus in bulls from Alagoas 
State, Brazil was confirmed. Accordingly, it is recommended to conduct laboratory examinations focused on sexually transmitted diseases in rural properties breeding reproducers in order to reduce the financial impacts caused by them.

\section{Ethical aspects}

The research was approved by the Ethical Commission on Animal Use of Pernambuco Federal University (License n. 108/2015).

\section{Conflict of interest}

The authors declare no conflict of interest.

\section{Acknowledgments}

The authors are grateful to CAPES for the $\mathrm{PhD}$ scholarship and to CNPq for the productivity scholarship granted to the last author (process $n$. 305072/2015-3).

\section{References}

BELlOWS, D. S.; OTT, S. L.; BELLOWS, R. A. Review: cost of reproductive diseases and conditions in cattle. The Professional Animal Scientist, Champaign, v. 18, n. 1, p. 26-32, 2002.

BONDURANT, R. H. Venereal diseases of cattle: natural history, diagnosis, and the role of vaccines in their control. Veterinary Clinics of North America: Food Animal Practice, Philadelphia, v. 21, n. 2, p. 383-408, 2005.

BURNS, B. M.; FORDYCE, G.; HOLROYDA, R. G. A review of factors that impact on the capacity of beef cattle females to conceive, maintain a pregnancy and wean a calf implications for reproductive efficiency in northern Australia. Animal Reproduction Science, Amsterdam, v. 122, n.1-2, p. 1-22, 2010.

CAMPERO, C. M.; COBO, E. R. Tritrichomonas foetus: patogénesis de la mortalidad embrionaria/fetal, caracterización de antígenos vacunales y respuesta inmune inducida. Revista de Medicina Veterinaria, Bs As Argentina, Buenos Aires, v. 87, p. 47-56, 2006.
CLARK, B. L.; PARSONSON, I. M.; DUFTY, J. H. Experimental infection of bulls with Tritrichomonas foetus. Australian Veterinary Journal, New South Wales, v. 50, n. 5, p. 189-191, 1974.

COLLANTES-FERNÁNDEZ, E.; MENDOZAIBARRA, J. A.; PEDRAZA-DÍAZ, S.; ROJOMONTEJO, S.; NAVARRO-LOZANO, V.; SÁNCHEZSÁNCHEZ, R.; RUIZ-SANTA-QUITERIA， J. A.; ORTEGA-MORA, L. M.; OSORO, K. Efficacy of a control program for bovine trichomonosis based on testing and culling infected bulls in beef cattle managed under mountain pastoral systems of Northern Spain. The Veterinary Journal, London, v. 200, n. 1, p. 140-145, 2014.

DUFERNEZ, F.; WALKER, R.; NOËL, C.; CABY, S.; MANTINI, C.; DELGADO-VISCOGLIOSI, P.; OHKUMA, M.; KUDO, T.; CAPRON, M.; PIERCE, R. J.; VILLANUEVA, M. R.; VISCOGLIOSI, E. Morphological and molecular identification of nonTritrichomonas foetus trichomonad protozoa from the bovine preputial cavity. Journal Eukaryotic Microbiology, Lawrence, v. 54, n. 2, p. 161-168, 2007.

EAGLESOME, M. D.; GARCIA, M. M. Disease risks to animal health from artificial insemination with bovine semen. Revue Scientifique et Technique, Paris, v. 16, n. 1, p. 215-225, 1997.

FELLEISEN, R. S. J. Comparative sequence analysis of 5 8S rRNA genes and internal transcribed spacer (ITS) regions of trichomonadid protozoa. Parasitology, v. 115, n. 2, p. 111-119, 1997.

GONZÁLEZ-CARMONA, L. C.; SÁNCHEZ-LADINO, M. J.; CASTAÑEDA-SALAZAR, R.; PULIDOVILLAMARÍN, A. D. P.; GUÁQUETA-MUNAR, H.; ARANDA-SILVA, M.; RUEDA-VARÓN, M. J. Determination of presence of Tritrichomonas foetus in uterine lavages from cows with reproductive problems. Revista Brasileira de Parasitologia Veterinária, Jaboticabal, v. 21, n. 3, p. 201-205, 2012.

HANCOCK, A. S.; YOUNIS, P. J.; BEGGS, D. S.; MANSELL, P. D.; PYMAN, M. F. Infectious reproductive disease pathogens in dairy herd bulls. Australian Veterinary Journal, New South Wales, v. 93, n. 10, p. 349-353, 2015.

HUM, S.; HORNITZKY, M.; BERG, T. Bovine genital campylobacteriosis. Australia and New Zealand Standard Diagnostic Procedures, SCAHLS (Department of Agriculture, Fisheries and Forestry) Camden, p. 1-19, 2009.

HUM, S.; QUINN, K.; BRUNNER, B.; ON, S. L. W. Evaluation of a PCR assay for indentification and 
differentiation of Campylobacter fetus subspecies. Australian Veterinary Journal, New South Wales, v. 75, n. 11, p. 827-831, 1997.

INSTITUTO BRASILEIRO DE GEOGRAFIA E ESTATÍSTICA - IBGE. Sistema IBGE de Recuperação Automática - SIDRA. Pecuária 2016. Rio de janeiro, 2016. Disponível em: <https://ww2.ibge.gov.br / estadosat/temas.php? sigla $=$ al\&tema $=$ pecuaria2016>. Acesso em: 15 ago. 2017.

JIMENEZ, D. F.; PEREZ, A. M.; CARPENTER, T. E.; MARTINEZ, A. Factors associated with infection by Campylobacter fetus in beef herds in the Province of Buenos Aires, Argentina. Preventive Veterinary Medicine, Colorado, v. 101, n. 3-4, p. 157-162, 2011.

LEAL, D. R.; FERNANDES, G. O.; GOUVEIA, F. F.; MIRANDA K. L.; NEVES J. P. Prevalência da campilobacteriose e da tricomonose genitais bovinas no Distrito Federal e em seu entorno. Revista Brasileira de Reprodução Animal, Belo Horizonte, v. 36, n. 4, p. 256259, 2012.

MADOROBA, E.; GELAW, A.; HLOKWE, T.; MNISI, M. Prevalence of Campylobacter foetus and Trinchomonas foetus among cattle from Southern Africa. African Journal of Biotechnology, Nairobi, v. 10, n. 50, p. 10311-10314, 2011.

MAI, H. M.; IRONS, P. C.; KABIR, J.; THOMPSON, P. N. Prevalence of bovine genital campylobacteriosis and trichomonosis of bulls in northern Nigeria. Acta Veterinaria Scandinavica, London, v. 55, n. 56, p. 1-10, 2013.

MARDONES, F. O.; PEREZ, A. M.; MARTINEZ, A.; CARPENTER, T. E. Risk factors associated with Tritrichomonas foetus infection in beef herds in the province of Buenos Aires, Argentina. Veterinary Parasitology, Amsterdam, v. 153, n. 3-4, p. 231-237, 2008.

MICHI, A. N.; FAVETTO, P. H.; KASTELIC, J.; COBO, E. R. A review of sexually transmitted bovine trichomoniasis and campylobacteriosis affecting cattle reproductive health. Theriogenology, New York, v. 85, n. 5, p. 781-791, 2016.

MOLINA, L.; PEREA, J.; MEGLIA, G.; ANGÓN, E.; GARCIA,A. Spatial and temporal epidemiology of bovine trichomoniasis and bovine genital campylobacteriosis in La Pampa province (Argentina). Preventive Veterinary Medicine, Colorado, v. 110, n. 3-4, p. 388- 394, 2013.

MSHELIA, G. D.; AMIN, J. D.; WOLDEHIWET, Z.; MURRAY, R. D.; EGWU, G. O. Epidemiology of bovine venereal campylobacteriosis: geographic distribution and recent advances in molecular diagnostic techniques.
Reproduction in Domestic Animals, Berlin, v. 45, n. 5, p. 221-230, 2010.

MUTTO, A. A.; GIAMBIAGGI, S.; ANGEL, S. O. PCR detection of Tritrichomonas foetus in preputial bull fluid without prior DNA isolation. Veterinary Parasitology, Amsterdam, v. 136, n. 3-4, p. 357-361, 2006.

OLIVEIRA, J. M. B.; BATISTA FILHO, A. F. B.; BORGES, J. M.; SOARES, B. F.; ORTEGA-MORA, L. M.; BRANDESPIM, D. F.; MOTA, R. A.; PINHEIRO JUNIOR, J. W. Tritrichomonas foetus in bulls in the State of Pernambuco, Brazil. Revista Brasileira de Medicina Veterinária, Rio de Janeiro, v. 38, n. 4, p. 449-453, 2016.

OLIVEIRA, J. M. B.; SILVA, G. M.; BATISTA FILHO, A. F. B.; BORGES, J. M.; OLIVEIRA, P. R. F.; BRANDESPIM, D. F.; MOTA, R. A.; PINHEIRO JUNIOR, J. W. Prevalence and risk factors associated with bovine genital campylobacteriosis and bovine trichomonosis in the state of Pernambuco, Brazil. Tropical Animal Health and Production, Edinburgh, Livingstone., v. 47, n. 3, p. 549-555, 2015.

ONDRAK, J. D. Tactics for identifying and eliminating Tritricomonas foetus from infected beef herds. Lincoln: University of Nebraska, 2010. 147 p.

PELlEGRIN, A. O.; LEITE, R. C.; SERENO, J. R. B.; REINATO, A. P. R.; LAGE, A. P. Prevalência da campilobacteriose genital bovina em touros Nelore do Pantanal Mato-Grossense. Corumbá: EMBRAPA Pantanal, 1999. 11 p. (EMBRAPA Pantanal. Comunicado técnico, 23).

PEREIRA-NEVES, A.; BENCHIMOL, M. Tritrichomonas foetus: budding from multinucleated pseudocysts. Protist, Jena, v. 160, n. 4, p. 536-551, 2009.

PEREIRA-NEVES, A.; CAMPERO, C. M.; MARTÍNEZ, A.; BENCHIMOL, M. Identification of Tritrichomonas foetus pseudocystis in fresh preputial scretion samples bulls. Veterinary Parasitology, Amsterdam, v. 175, n. 1-2, p. 1-8, 2011.

PEREIRA-NEVES, A.; RIBEIRO, K. C.; BENCHIMOL, M. Pseudocysts in trichomonads-new insights. Protist, Jena, v. 154, n. 3-4, p. 313-329, 2003.

ROCHA, F. S.; JESUS, V. L. T.; TORRES, H. M.; GOMES, M. J. P.; FIGUEIREDO, M. J.; NASCIMENTO, E. R.; FERREIRA, T.; AQUINO, M. H. C. Investigação de Campylobacter e Tritrichomonas foetus na mucosa prepucial de touros da região do Médio Paraíba, RJ. Ciência Rural, Santa Maria, v. 39, n. 5, p. 1586-1589, 2009.

SWAI, E. S.; HULSEBOSCHB, J.; VAN DER HEIJDENB, W. Prevalence of genital campylobacteriosis and trichomonosis in crossbred breeding bulls kept on 
zero-grazed smallholder dairy farms in the Tanga region of Tanzania. Journal of the South African Veterinary Association, Cape Town, v. 76, n. 4, p. 224-227, 2005.

TRUYERS, I.; LUKE, T.; WILSON, D.; SARGISON, $\mathrm{N}$. Diagnosis and management of venereal campylobacteriosis in beef cattle. BMC Veterinary Research, London, v. 10, n. 280, p. 1-7, 2014.

WALDNER, C. L.; PARKER, S.; GESY, K. M.; WAUGH, T.; LANIGAN, E.; CAMPBELL, J. R. Application of direct polymerase chain reaction assays for Campylobacter fetus subsp. venerealis and Tritrichomonas foetus to screen preputial samples from breeding bulls in cow-calf herds in western Canada. The Canadian Journal of Veterinary Research, Ottawa, v. 81, n. 2, p. 91-99, 2017.

YAO, C. Tritrichomonas foetus infections in female beef cattle with abortion in Wyoming, USA. Journal of Medical Microbiology, Reading, v. 2, n. 2, p. 1-5, 2015.

YINZHU, J.; SCHUMAKER, B.; LOGAN, J.; YAO, C. Risk factors associated with bovine trichomoniasis in beef cattle identified by a questionnaire. Journal of Medical Microbiology, Reading, v. 63, n. 6, p. 896-902, 2014. 
